\title{
Completeness of tuberculosis reporting forms for disease control in individuals with HIV/AIDS in priority cities of Bahia state
}

\author{
Monique Lírio ${ }^{1}$ \\ Normeide Pedreira dos Santos ${ }^{2}$ \\ Louran Andrade Reis Passos ${ }^{3}$ \\ Afrânio Kritski ${ }^{4}$ \\ Bernardo Galvão-Castro ${ }^{2}$ \\ Maria Fernanda Rios Grassi ${ }^{2}$
}

${ }^{1}$ Complexo Hospitalar Professor Edgard Santos, Universidade Federal da Bahia. R. Doutor Augusto Viana s/n, Canela. 40110060 Salvador BA Brasil. monique.lirio@

yahoo.com.br

${ }^{2}$ Curso de Pós-Graduação, Escola Baiana de Medicina e Saúde Pública.

${ }^{3}$ Curso de Graduação em Medicina, Escola Baiana de Medicina e Saúde Pública.

${ }^{4}$ Faculdade de Medicina,

Universidade Federal do Rio de Janeiro.

\begin{abstract}
The control of HIV / Tuberculosis (TB) co-infection remains a challenge for public health. Notification is mandatory for both diseases and the National Case Registry Database (Sinan) is responsible for the collection and processing of individual forms of reporting and monitoring. The adequate fulfilment of these fields chips (completeness) is essential to follow the dynamics of the disease and set priorities for intervention. The aim of this study was to evaluate the completeness of the notification forms of tuberculosis in the priority municipalities of Bahia (Camaçari, Feira de Santana, Ilhéus, Itabuna, Jequié, Lauro de Freitas, Porto Seguro, Teixeira de Freitas, Paulo Afonso, Barreiras and Salvador) to control the disease in individuals with HIV/AIDS using tabulations obtained from the Sinan in the period from 2001 to 2010. The results showed that despite the completeness of the field HIV be above 50 $\%$, more than half the cases were met as "undone" or "being processed" in all municipalities assessed in the period. The low completeness of reporting forms may compromise the quality of surveillance of TB cases. The results suggest the need for greater availability of HIV testing in these individuals. Key words Tuberculosis, HIV, Public health surveillance, Disease notification
\end{abstract}




\section{Introduction}

Tuberculosis (TB) was under control in developed countries until the mid-1980s. However, after the emergence of the HIV / AIDS epidemic, the number of TB cases raised sharply. In the 1990s, TB was considered the second epidemic disease in Asia, Africa and Latin America and declared as a global emergency by WHO in $1993^{1}$. From the 1990s to 2012, the overall prevalence of TB dropped off $37 \%$. Yet, the goal of $50 \%$ of TB cases reduction set by WHO until 2015is still far from being achieved ${ }^{2}$.

Currently, Brazil ranks the 17th higher for the burden of TB among the 22 higher-burden countries $^{3}$. Bahia is the third Brazilian state with higher total number of TB cases and the tenth among the states with higher incidence of the disease in the country4.

The control of HIV / TB co-infection remains a challenge to public health. Although TB diagnosis and treatment are available, TB causes more than a quarter of deaths in people living with HIV/AIDS worldwide ${ }^{5}$. In addition, approximately $43 \%$ of HIV/TB co-infected patients have resistance to tuberculostatic drugs ${ }^{6}$.

The prevalence of HIV/TB co-infection is more frequent in areas with high TB-burden. At the end of the 1990s, the relative risk of HIV/TB co-infection in Latin America was about three times higher than in United States, where HIV prevalence reaches $11 \%$ of individuals with $\mathrm{TB}^{7}$. In Brazil, $20 \%$ of patients infected with Mycobacterium tuberculosis has a positive HIV serology ${ }^{8}$, while in Bahia state, $8.8 \%$ of patients hospitalized with TB were infected with HIV 9

AIDS and TB are both diseases with mandatory notification at the Sistema de Informação de Agravos de Notificação (Sinan, Brazilian Case Registry Database), organization responsible for collecting and processing individual notification forms and follow-up of the cases ${ }^{10}$. Proper completion of all fields of these records (completeness) is essential to survey the disease dynamic and for priority setting of health intervention ${ }^{11}$. The lack of data exchange between AIDS and TB programs can contribute to adverse outcomes such as mortality, which reaches more than $50 \%$ of HIV/TB co-infected patients ${ }^{12}$.

In order to restructure and improve the assistance to severe cases of TB (adverse reactions, drug resistance and co-morbidities such as diabetes, hepatitis and HIV / AIDS), the National Tuberculosis Control Program (NTCP) established new criteria to define priority cities for $\mathrm{TB}$ control in 2009. The current criteria include all capitals, cities with population greater or equal to 100,000 inhabitants, cities with TB incidence higher than $80 \%$ of the national level or with TB mortality higher than the national rate ${ }^{13}$. Currently, there are 181 priority cities in Brazil, 11 of which are located in Bahia ${ }^{4}$.

The aim of this study was to evaluate the completeness of TB notification forms in people living with HIV / AIDS in priority cities for TB control in Bahia state.

\section{Methods}

This is a descriptive study, with data collected from Sinan reports for a ten years period (January 2001 to December 2010). The sample included reports from all priority cities in the state of Bahia: Camaçari, Feira de Santana, Ilhéus, Itabuna, Jequié, Lauro de Freitas, Porto Seguro, Teixeira de Freitas, Paulo Afonso and Barreiras, in addition to Salvador, the capital of the state ${ }^{4}$. Data were collected by three undergraduate students previously trained and revised in a second time by the researchers.

Completeness of HIV and AIDS fields of all TB notification forms was analyzed. Additionally, we evaluated seven other variables related to co-infection: sputum smear $\left(1^{\text {st }}\right.$ and $2^{\text {nd }}$ from the first month, $2^{\text {nd }}$ month and $6^{\text {th }}$ month), sputum culture, clinical presentation of tuberculosis and outcome.

Analysis of completeness was based on the Sinan classification for qualitative assessment: category 1 if there was $0-25 \%$ of completeness; category 2 between $25.1 \%$ and $50 \%$; Category 3 between $50.1 \%$ and $75 \%$ and category 4 between $75.1 \%$ and $100 \%{ }^{14}$. The rating previously proposed by Sinan categorized the completeness as excellent if fields were filled up to $90 \%$, regular between 70 and $89 \%$ and poor if below $70 \%{ }^{15}$. Fields "ignored" or "blank" were considered incomplete and excluded.

\section{Results}

A total of 44,952 TB notifications forms were evaluated in the priority cities, accounting for $59.7 \%$ of all TB cases in the state $(75,246)$ during the ten years of the study. Salvador had the highest absolute number of notifications $(33,987)$, followed by Feira de Santana (2,519), Itabuna $(1,740)$ and Ilhéus $(1,417)$. 
Table 1 depicts the completeness of TB notification forms for the HIV and AIDS variables. For HIV field, completeness ranged from $64.7 \%$ (Jequié) to $95.6 \%$ (Feira de Santana). Jequié and Itabuna were classified as Category 3 and the other cities as category 4.The percentage of fields filled in as "ongoing" or "not performed" accounted for more than $57 \%$ in all evaluated cities, ranging from $57.2 \%$ in Porto Seguro to $89.6 \%$ in Itabuna. Feira de Santana, the city with the highest completeness of HIV field, had the highest percentage of fields filled as "not performed" (84.5\%). The number of HIV positive cases was 2,025 , representing $4.5 \%$ of the notifications in the period $(44,952)$.

Regarding to the AIDS variable, completeness rates were below $50 \%$ in all municipalities, ranging from $10.1 \%$ (Barreiras) to $40.6 \%$ (Lauro de Freitas). Seven cities were classified as category 1: Barreiras (10.1\%), Ilhéus (13.5\%), Itabuna (17.5\%), Jequié (15.4), Porto Seguro
(23.4\%), Salvador (23.6\%) and Teixeira de Freitas $(17.5 \%)$, while all others cities were considered as category 2 .

Table 2 shows the completeness of the variables related to the co-infection HIV / TB: The $1^{\text {st }}$ smear and clinical presentation variables obtained $100 \%$ of completeness (category 4 ) in all evaluated cities. The $2^{\text {nd }}$ smear variable was classified as category 2 in seven cities and as category 4 in only one, whereas the others cities were classified as category 3 . The lowest completeness rates to the variables smear in the $2^{\text {nd }}$ and in the $6^{\text {th }}$ month were found in Teixeira de Freitas (29.2\% and $16.7 \%$ respectively) and the highest in Feira de Santana ( $89.2 \%$ and $79.7 \%)$. The outcome field was considered as category 4 for nine cities and category 3 for the other two.

The completeness of the variables related to patients with AIDS diagnosis and TB are described in Table 3: the completeness of the $1^{\text {st }}$ smear was classified as categories 2, 3 and 4 for

Table 1. Completeness of HIV and AIDS variables, state of Bahia. Period: January, 2001 - December, 2010.

\begin{tabular}{|c|c|c|c|c|c|c|}
\hline \multirow[b]{2}{*}{ Municipality } & \multirow[b]{2}{*}{ Notifications } & \multicolumn{5}{|c|}{ HIV } \\
\hline & & $\begin{array}{c}\text { Completeness } \\
\text { n }(\%)\end{array}$ & $\begin{array}{c}\text { Positive } \\
\text { n (\%) }\end{array}$ & $\begin{array}{l}\text { Negative } \\
\mathbf{n}(\%)\end{array}$ & $\begin{array}{l}\text { Ongoing } \\
\text { n (\%) }\end{array}$ & $\begin{array}{c}\text { Not performed } \\
\text { n }(\%)\end{array}$ \\
\hline Barreiras & 571 & $510(89.3)$ & $12(2.1)$ & $209(36.60)$ & $61(10.7)$ & $289(50.6)$ \\
\hline Camaçari & 1,070 & $955(89.2)$ & $27(2.5)$ & $241(22.52)$ & $112(10.5)$ & $687(64.2)$ \\
\hline Feira de Santana & 2,519 & 2,408 (95.59) & $74(2.9)$ & $206(8.2)$ & $111(4.41)$ & $2,128(84.5)$ \\
\hline Ilhéus & 1,417 & $1,261(88.99)$ & $45(3.17)$ & $217(15.3)$ & $156(11.0)$ & $999(70.5)$ \\
\hline Itabuna & 1,740 & 1,302 (74.8) & $46(2.6)$ & $136(7.8)$ & $438(25.2)$ & $1.120(64.4)$ \\
\hline Jequié & 911 & $589(64.7)$ & $26(2.9)$ & $225(24.70)$ & $319(35.0)$ & $338(37.1)$ \\
\hline Lauro de Freitas & 556 & $479(86.2)$ & $18(3.2)$ & $159(28.60)$ & $74(13.3)$ & $302(54.3)$ \\
\hline Paulo Afonso & 436 & $404(92.7)$ & $8(1.8)$ & $82(18.8)$ & $32(7.3)$ & $314(72.0)$ \\
\hline Porto Seguro & 753 & $577(76.6)$ & $50(6.6)$ & $271(35.99)$ & $175(23.2)$ & $256(34.0)$ \\
\hline Salvador & 33,987 & $27,176(79.99)$ & $1,695(4.99)$ & $3,439(10.1)$ & $6,713(19.8)$ & $22,042(64.9)$ \\
\hline \multirow[t]{2}{*}{ Teixeira de Freitas } & 992 & $790(79.64)$ & $24(2.4)$ & $185(18.65)$ & $201(20.26)$ & $581(58.57)$ \\
\hline & & \multicolumn{5}{|c|}{ AIDS } \\
\hline Municipality & Notifications & \multicolumn{2}{|c|}{$\begin{array}{c}\text { Completeness } \\
\text { n (\%) }\end{array}$} & \multicolumn{2}{|c|}{$\begin{array}{c}\text { Yes } \\
\mathbf{n}(\%)\end{array}$} & $\begin{array}{l}\text { No } \\
\text { n }(\%)\end{array}$ \\
\hline Barreiras & 571 & \multicolumn{2}{|r|}{$58(10.1)$} & \multicolumn{2}{|c|}{$11(1.9)$} & $47(8.2)$ \\
\hline Camaçari & 1,070 & \multicolumn{2}{|r|}{$309(28.9)$} & \multicolumn{2}{|c|}{$21(2)$} & $288(26.9)$ \\
\hline Feira de Santana & 2,519 & \multicolumn{2}{|r|}{$722(28.6)$} & \multicolumn{2}{|c|}{$61(2.4)$} & $661(26.2)$ \\
\hline Ilhéus & 1,417 & \multicolumn{2}{|r|}{$192(13.5)$} & \multicolumn{2}{|c|}{$34(2.4)$} & $158(11.1)$ \\
\hline Itabuna & 1,740 & \multicolumn{2}{|r|}{$305(17.5)$} & \multicolumn{2}{|c|}{$31(2.8)$} & $274(14.7)$ \\
\hline Jequié & 911 & \multicolumn{2}{|r|}{$140(15.4)$} & \multicolumn{2}{|c|}{$11(1.2)$} & $129(14.2)$ \\
\hline Lauro de Freitas & 556 & \multicolumn{2}{|r|}{$226(40.6)$} & \multicolumn{2}{|c|}{$16(2.9)$} & $210(37.7)$ \\
\hline Paulo Afonso & 436 & \multicolumn{2}{|r|}{$121(27.9)$} & \multicolumn{2}{|c|}{$6(1.4)$} & $116(26.5)$ \\
\hline Porto Seguro & 753 & \multicolumn{2}{|c|}{$176(23.4)$} & \multicolumn{2}{|c|}{$34(2.5)$} & $142(20.9)$ \\
\hline Salvador & 33,987 & \multicolumn{2}{|c|}{$8,008(23.6)$} & \multicolumn{2}{|c|}{$1,497(4.4)$} & $6,517(19.2)$ \\
\hline Teixeira de Freitas & 992 & \multicolumn{2}{|c|}{$174(17.5)$} & \multicolumn{2}{|c|}{$26(9.2)$} & $148(8.3)$ \\
\hline
\end{tabular}


Table 2. Completeness of the variables: smear, sputum culture, clinical form and outcome in co-infected individuals with TB/HIV, state of Bahia. Period: January, 2001 - December, 2010.

\begin{tabular}{|c|c|c|c|c|c|c|c|}
\hline \multirow[b]{2}{*}{$\begin{array}{c}\text { Individuals } \\
\text { with HIV/TB (n) }\end{array}$} & \multirow[b]{2}{*}{$\begin{array}{c}1^{\text {st }} \\
\text { smear }\end{array}$} & \multicolumn{6}{|c|}{ Completeness n (\%) } \\
\hline & & $\begin{array}{c}2^{\text {st }} \\
\text { smear }\end{array}$ & $\begin{array}{c}\text { Smear } \\
2^{\text {nd }} \text { month }\end{array}$ & $\begin{array}{c}\text { Smear } \\
6^{\text {th }} \text { month }\end{array}$ & $\begin{array}{l}\text { Sputum } \\
\text { culture }\end{array}$ & $\begin{array}{l}\text { Clinical } \\
\text { form }\end{array}$ & Outcome \\
\hline Barreiras (12) & $12(100)$ & $10(83.3)$ & $10(83.3)$ & $8(66.7)$ & $12(100)$ & $12(100)$ & $12(100)$ \\
\hline Camaçari (27) & $27(100)$ & $14(51.9)$ & $22(81.5)$ & $17(62.96)$ & $25(92.59)$ & $27(100)$ & $26(96.3)$ \\
\hline Feira de Santana (74) & $74(100)$ & $35(47.3)$ & $66(89.2)$ & 59 (79.7) & $72(97.3)$ & $74(100)$ & $71(95.95)$ \\
\hline Ilhéus (45) & $45(100)$ & $20(44.4)$ & $32(71.11)$ & $24(53.33)$ & $36(80.00)$ & $45(100)$ & 45 (100) \\
\hline Itabuna (46) & $46(100)$ & $22(47.8)$ & $38(82.6)$ & $31(67.4)$ & $42(91.3)$ & $46(100)$ & $45(97.8)$ \\
\hline Jequié (26) & $26(100)$ & $8(30.8)$ & $23(88.5)$ & $16(61.5)$ & $25(96.2)$ & $26(100)$ & $26(100)$ \\
\hline Lauro de Freitas (18) & $18(100)$ & $11(61.1)$ & $7(38.4)$ & $6(33.3)$ & $13(72.2)$ & $18(100)$ & $17(94.4)$ \\
\hline Paulo Afonso (8) & $8(100)$ & $6(75.0)$ & $5(62.5)$ & $4(50.00)$ & $8(100)$ & $8(100)$ & $8(100)$ \\
\hline Porto Seguro (50) & $50(100)$ & $21(42.0)$ & $20(40.00)$ & $14(28.00)$ & $46(92.00)$ & $50(100)$ & $50(100)$ \\
\hline Salvador $(1,695)$ & $1,695(100)$ & $799(47.1)$ & $664(39.2)$ & $572(33.8)$ & $1,247(73.6)$ & $1,695(100)$ & $1,162(68.6)$ \\
\hline Teixeira de Freitas (24) & $24(100)$ & $11(45.8)$ & $7(29.2)$ & $4(16.7)$ & $24(100)$ & $24(100)$ & $18(75.0)$ \\
\hline
\end{tabular}

Table 3. Completeness of the variables: smear, sputum culture, clinical form and outcome in individuals with TB and AIDS, state of Bahia. Period: January, 2001 - December, 2010.

\begin{tabular}{|c|c|c|c|c|c|c|c|}
\hline \multirow[b]{2}{*}{$\begin{array}{l}\text { Individuals with } \\
\text { TB and AIDS (n) }\end{array}$} & \multicolumn{7}{|c|}{ Completeness n (\%) } \\
\hline & $\begin{array}{c}1^{\text {st }} \\
\text { smear }\end{array}$ & $\begin{array}{c}2^{\text {st }} \\
\text { smear }\end{array}$ & $\begin{array}{c}\text { Smear } \\
2^{\text {nd }} \text { month }\end{array}$ & $\begin{array}{c}\text { Smear } \\
6^{\text {th }} \text { month }\end{array}$ & $\begin{array}{l}\text { Sputum } \\
\text { culture }\end{array}$ & $\begin{array}{l}\text { Clinical } \\
\text { form }\end{array}$ & Outcome \\
\hline Barreiras (11) & $8(72.7)$ & $6(54.5)$ & $5(45.4)$ & $5(45.4)$ & $4(45.4)$ & $11(100)$ & $11(100)$ \\
\hline Camaçari (21) & $17(80.9)$ & $7(33.3)$ & $6(28.6)$ & $5(23.8)$ & $5(23.8)$ & $21(100)$ & $21(100)$ \\
\hline Feira de Santana (61) & $25(41)$ & $14(22.9)$ & $7(11.5)$ & $5(8.2)$ & $5(8.2)$ & $61(100)$ & $58(95.1)$ \\
\hline Ilhéus (34) & $23(67.3)$ & $10(29.4)$ & $10(29.4)$ & $8(23.5)$ & $8(23.5)$ & $34(100)$ & $34(100)$ \\
\hline Itabuna (31) & $18(58)$ & $8(25.8)$ & $8(25.8)$ & $1(3.2)$ & $1(3.2)$ & $31(100)$ & $30(96.8)$ \\
\hline Jequié (11) & $6(54.5)$ & $3(27.3)$ & $4(36.7)$ & $3(27.3)$ & $3(27.3)$ & $11(100)$ & $11(100)$ \\
\hline Lauro de Freitas (16) & $14(87.5)$ & $8(50)$ & $3(18.7)$ & $3(18.7)$ & $3(18.7)$ & $16(100)$ & $15(93.7)$ \\
\hline Paulo Afonso (6) & $5(83.3)$ & $4(66.7)$ & $0(0)$ & $1(16.7)$ & $1(16.7)$ & $6(100)$ & $6(100)$ \\
\hline Porto Seguro (34) & $17(50)$ & $4(11.8)$ & $9(26.5)$ & $9(26.5)$ & $9(26.5)$ & $34(100)$ & $34(100)$ \\
\hline Salvador $(1,497)$ & $985(65.8)$ & $370(24.7)$ & $165(11)$ & $106(7.1)$ & $106(7.1)$ & $1,497(100)$ & $1,008(63.3)$ \\
\hline Teixeira de Freitas (26) & $15(57.7)$ & $2(7.7)$ & 7 (26.9) & $3(11.5)$ & $3(11.5)$ & $26(100)$ & $20(76.9)$ \\
\hline
\end{tabular}

2, 6 and 3 cities, respectively. Regarding the $2^{\text {nd }}$ smear, two cities were classified as completeness 3 (Barreiras and Paulo Afonso) and the others, as categories 1 and 2 . In all cities, the smear of the $2^{\text {nd }}$ and the $6^{\text {th }}$ months and sputum culture variables were classified as categories 1 and 2. For the variable clinical presentation, all municipalities reached completeness 4 and for the variable outcome, only Salvador was classified as category 3 , while the other cities were category 4 .

\section{Discussion}

The results of the present study indicate that the completeness of HIV and AIDS fields of TB notification forms is below the level set by the Brazilian Ministry of Health.

The need to improve access to HIV testing in individuals with tuberculosis has been described in the literature. Sanchez et al. ${ }^{16}$ evaluated the clinical outcome of TB in individuals infected or not with HIV and reported that the serology was not available for $32 \%$ of TB cases reported in Brazil between 2003 and 2008. In the same study, the risk of an unfavorable outcome was three 
times higher in HIV-infected patients compared to HIV-uninfected individuals. An intermediate risk of unfavorable TB outcome was found in the group who did not perform HIV serology, suggesting the possibility of undiagnosed HIV-infected individuals.

In Brazil, AIDS as well as alcoholism and malnutrition play an important role in determining high TB mortality rates ${ }^{17}$.

In the present study, although the completeness of HIV field was considered as categories 3 and 4, more than half of fields were filled as "not performed" or "ongoing" in all cities evaluated. The low number of HIV tests performed contradicts the Brazilian Ministry of Health recommendation for testing the virus infection in all patients with $\mathrm{TB}^{18}$. This fact might impair the care assistance and delay the development of preventive actions and injury control. The high percentage of fields filled as "ongoing" might be explained by delay in releasing the HIV results or updating the data in Sinan database by local health departments. Appropriate actions should be undertaken to correct these difficulties.

It is noteworthy that WHO considers as priorities to TB control both the availability of HIV tests and antiretroviral therapy for all HIV/TB co-infected individuals ${ }^{2}$.

The "linkage" strategy (record linkage) should be employed in order to recover missing data from databases such as Mortality Information System data, Laboratory Tests Control System of the National Network of CD4 + / CD8 + Lymphocyte Count and viral load, the System of Medication Logistic Control and Sinan / AIDS ${ }^{19}$. Using this strategy and training health care professionals of surveillance are needed to improve the completeness of Sinan data.

Regarding the AIDS variable, the completeness was under $50 \%$ in all evaluated cities, lower than HIV field. The difference between completeness of HIV and AIDS variables may be related to the guidelines to fill the forms ${ }^{20}$ : filling HIV field is mandatory to launch the notification in the Sinan database, while AIDS field is considered as an essential variable (not filling it affects the development of specific actions for co-infection control, but does not preclude the case report). Likewise, clinical presentation was classified as category 4 in all cities, which might be explained because this is a mandatory filed in patients with AIDS / TB. The outcome field, despite being an essential variable, was classified as category 4 in almost all (10/11) cities, probably due to its importance in defining the effectiveness and quality of National Tuberculosis Control Program actions in the city, especially in regard to HIV / TB co-infection. It is noteworthy that this co-infection is considered a major factor to acquire resistance to tuberculostatic drugs ${ }^{18}$, which has become a serious problem in developed and developing countries.

The paucity of information in all fields with low completeness may still be related to the misconception of some health professionals that reporting forms represent a purely bureaucratic issue, with no impact on the panorama of public health ${ }^{21}$.

Several models for evaluation of tuberculosis control program has been proposed and factors such as lack of technical and managerial autonomy, absence of human, financial and material resources as well as failure of integration between programs have been identified as major problems for development of actions to the disease control ${ }^{22}$.

It is important to point that a limitation of this study is using secondary data with probable delay in the records updating by local health departments. In addition, it was not possible to determine the prevalence of the co-infection HIV / TB, due to the low number of HIV tests performed. However, the results obtained are relevant. This is a pioneer study since evaluates the priority cities to TB notification in Bahia, for a decade. The knowledge of these results may elicit actions to reverse the current scenario.

\section{Collaborations}

M Lírio, NP Santos, LAR Passos, A Kritski, B Galvão-Castro and MFR Grassi participated equally in all stages of preparation of the article. 


\section{References}

1. Dye C, Scheele S, Dolin P, Pathania V, Raviglione MC. WHO Global Surveillance and Monitoring Project. Global Burden of Tuberculosis: Supplemental Appendixes. JAMA 1999; 282(7):677-686.

2. World Health Organization (WHO). Global Report Tuberculosis 2013. Geneva: WHO; 2013.

3. Brasil. Ministério da Saúde (MS). Portal da Saúde notícias. [homepage onthe Internet]. [cited 2012 May 24]. Disponível em http://portal.saude.gov.br/portal/ aplicacoes/noticias/default.cfm?pg=dspDetalheNoticia \&id_area $=124 \&$ CO_NOTICIA $=1165$.

4. Bahia. Diretoria de Vigilância Epidemiológica (DIVEP) da Bahia. Boletim Epidemiológico da Tuberculose Bahia, 2011. [homepage onthe Internet]. [cited 2012 May 24]. Disponível em http://www.suvisa.ba.gov.br/ sites/default/files/Boletim\%20TB\%20dez2011_0_0. pdf

5. Ghebreyesus TA, Kazatchkine M, Sidibé M, Nakatani H. Tuberculosis and HIV: time for an intensified response. Lancet 2010; 375(9728):1757-1758.

6. Campos PE, Suarez PG, Sanchez J, Zavala D, Arevalo J, Ticona E, Nolan CM, Hooton TM, Holmes KK. Multidrug-resistant Mycobacterium tuberculosis in HIV-infected persons, Peru. Emerg Infect Dis 2003; 9(12):1571-1578.

7. Santos JS, Beck ST. A coinfecção tuberculose e HIV: um importante desafio - Artigo de revisão. RBAC 2009; 41(3):209-215.

8. Brasil. Ministério da Saúde (MS). Co-infecção HIV/TB: resposta nacional e integração das agendas. [homepage on the Internet]. [cited 2012 Oct 16]. Disponível em: portal.saude.gov.br/portal/.../painel3_aids_mariangela _draurio.pdf

9. Matos ED, Lemos ACM, Bittencourt C, Mesquita CL, Kuhn PC. Prevalence of HIV Infection in Patients Hospitalized for Tuberculosis in Bahia, Brazil. Braz J Infect Dis 2007; 11(2):208-211.

10. Brasil. Portaria GM/MS no 2325 , de 8 de dezembro de 2003. Define a relação de doenças de notificação compulsória para todo território nacional. Diário Oficial da União 2003; 9 dez.

11. Brasil. Ministério da Saude (MS). Sinan - Sistema de Informação de Agravos de Notificação. Portal da Saúde. O que é o Sinan. [homepage on the internet]. [cited 2012 May 24]. Disponível em: http://dtr2004.saude. gov.br/sinanweb/index.php?name=Tnet

12. Miranda AE, Golub JE, Lucena FF, Maciel NE, Gurgel MF, Dietze R. Tuberculosis and AIDS co-morbidity in Brazil: linkage of the tuberculosis and AIDS databases. Braz J Infect Dis 2009; 13(2):137-141.

13. Brasil. Ministério da Saúde (MS). Secretaria de Vigilância em Saúde. Departamento de Vigilância das Doenças Transmissíveis. Programa Nacional de Controle da Tuberculose. Nota técnica $n^{\circ} 15$ CGPNCTIDEVEP/SVSIMS. Define critérios para a priorização de municípios no controle da tuberculose no Brasil. [homepage on the internet]. [cited 2012 Sep 28]. Disponível em: http:// portal.saude.gov.br/portal/arquivos/pdf/nota_tecnica_prioritarios.pdf
14. Brasil. Ministério da Saúde (MS). Sinan - Sistema de Informação de Agravos de Notificação. Tuberculose: instruções para o preenchimento da ficha de notificação/ investigação. [homepage on the internet]. [cited 2012 May 24]. Disponível em: http://www.sms.rio.rj.gov. $\mathrm{br} /$ coe/GTSINAN/Documenta\%E7\%E3o\%20SINAN/ Documenta\%E7\%E3o\%20do\%20sistema/Instrucionais $\% 20 \mathrm{de} \% 20$ preenchimento $\% 20$ das $\% 20$ fichas $/ \mathrm{Tu}$ berculose.pdf.

15. Brasil. Ministério da Saúde (MS). Programa Nacional de Controle da Tuberculose. Manual de Recomendações para o Controle da Tuberculose no Brasil. Brasil: MS; 2011.

16. Sanchez M, Bartholomay P, Arakaki-Sanchez D, Enarson D, Bissell K, Barreira D, Harries A, Kritski A. Outcomes of TB treatment by HIV status in national recording systems in Brazil, 2003-2008. PLoS One 2012; 7(3):e33129.

17. Vicentin G, Santo AH, Carvalho MS. Mortalidade por tuberculose e indicadores sociais no município do Rio de Janeiro. Cien Saude Colet 2002; 7(2):253-263.

18. Brasil. Ministério da Saúde (MS). Secretaria de Vigilância em Saúde. Departamento de Vigilância Epidemiológica. Manual de recomendações para o controle da tuberculose no Brasil. Brasília: MS; 2011.

19. Almeida MA, Alencar GP. Informações em Saúde: Necessidade de Introdução de Mecanismos de Gerenciamento dos Sistemas. Informe Epidemiológico do SUS 2000; 9(4):241-248.

20. Brasil. Ministério da Saúde (MS). Secretaria de Vigilância em Saúde. Sistema de Informação de Agravos de Notificação: Dicionário de Dados - SINAN NET. [acessado 2012 set 28]. Disponível em: http://dtr2004.saude.gov. br/sinanweb/novo/Documentos/SinanNet/dicionario/ DIC_DADOS_Tuberculose.pdf

21. Santos NP, Lírio M, Passos LAR, Dias JP, Kritski AL, Galvão-Castro B, Grassi MFR. Completude das fichas de notificações de tuberculose em cinco capitais do Brasil com elevada incidência da doença. Jornal Brasileiro de Pneumologia 2013; 39(2):221-225.

22. Oliveira LGD, Natal S, Felisberto E, Alves CKA, Santos EM. Modelo de avaliação do programa de controle da tuberculose. Cien Saude Colet 2010; 15(Supl. 1):9971008 .

Article submitted 10/13/2014

Approved 11/23/2014

Final version submitted 12/15/2014 